\title{
Estrogen Regulation of Gene Expression in GnRH Neurons
}

\author{
Yewade $\mathrm{Ng}^{1}$, Andrew Wolfe ${ }^{1}$, Horacio J. Novaira, and Sally Radovick \\ Johns Hopkins University School of Medicine Department of Pediatrics, Division of Endocrinology
}

\begin{abstract}
Estrogen plays an essential role in the regulation of the female reproductive hormone axis and specifically is a major regulator of GnRH neuronal function in the female brain. GnRH neuronal cell lines were used to explore the direct effects of estradiol on gene expression in GnRH neurons. The presence of estrogen receptor (ER) binding sites was established by a receptor binding assay and estrogen receptor $\alpha$ and $\beta$ mRNA were identified in GN11 cells and ER $\beta$ in GT1-7 cells using RTPCR analysis of mRNA. ER $\alpha$ was more abundantly expressed in GN11 cells than ER $\beta$ as assessed by real time PCR. Additionally, GN11 cells expressed significantly more of both ER $\alpha$ and $\beta$ than GT1-7 cells. Functional studies in GN11 and GT1-7 demonstrated estrogen down regulation of endogenous mouse GnRH mRNA levels using quantitative real-time PCR (qRT-PCR).

Correspondingly, estradiol also reduced secretion of GnRH from both the GN11 and GT1-7 cell lines. Since estradiol has been shown to regulate progesterone receptor (PR) expression; similar studies were performed demonstrating an estradiol mediated increase in PR in both cell lines. Estradiol regulation of ER expression was also explored and these studies indicated that estradiol decreased ER $\alpha$ and ER $\beta$ mRNA levels in a dose-dependent manner in GN11 and GT1-7 cells. These effects were blocked by the addition of the estrogen receptor antagonist ICI 182,780. Both PPT, a specific ER $\alpha$ agonist, and DPN, a specific ER $\beta$ agonist, inhibited GnRH gene expression in GN11 cells, but only DPN inhibited GnRH gene expression in GT1-7 cells, consistent with their undetectable levels of ER $\alpha$ expression. These studies characterize a direct inhibitory effect of estradiol on GnRH in GnRH neurons, and a direct stimulatory effect of estradiol on PR gene expression. In addition, the agonist studies indicate there is a functional overlap of ER $\alpha$ and ER $\beta$ regulation in GnRH neurons. These studies may give insight into the molecular regulation of estrogen negative feedback in the central reproductive axis.
\end{abstract}

\section{Keywords}

GnRH; Estrogen; Estrogen Receptor; Progesterone Receptor

\section{Introduction}

Estrogen is known to be a principal regulator of gonadotropin hormone-releasing hormone $(\mathrm{GnRH})$ neuronal function in the female brain. GnRH neurons in the hypothalamus synthesize and secrete the decapeptide GnRH which plays a pivotal role in regulating the cascade of

\footnotetext{
Corresponding Author: Andrew Wolfe, Johns Hopkins University School of Medicine, Department of Pediatrics, Division of Endocrinology, 600 North Wolfe St., CMSC406, Baltimore, MD 21287, Tel: 410-502-7916, Fax: 410-502-7580, E-mail: Awolfe3@jhmi.edu.

1 These authors contributed equally to this work

Publisher's Disclaimer: This is a PDF file of an unedited manuscript that has been accepted for publication. As a service to our customers we are providing this early version of the manuscript. The manuscript will undergo copyediting, typesetting, and review of the resulting proof before it is published in its final citable form. Please note that during the production process errors may be discovered which could affect the content, and all legal disclaimers that apply to the journal pertain.
} 
hormonal events, from pituitary gonadotropin release to ovarian maturation and estrogen production that are necessary for normal sexual maturation and normal reproductive function. Estrogen is known to have a bimodal effect on the hypothalamic-pituitary axis in females with both an inhibitory (Levine and Ramirez, 1980; Evans et al., 1995; Evans et al., 1994; Caraty et al., 1989; Sarkar and Fink, 1980; Chongthammakun and Terasawa, 1993) and stimulatory effect on GnRH and gonadotropin secretion. The stimulatory effect of estrogen on GnRH secretion is best illustrated at the end of the follicular phase where a gradual and sustained rise in circulating estrogen levels exerts a positive feedback effect on the hypothalamus triggering a preovulatory GnRH surge which, in turn, stimulates the preovulatory LH surge (Moenter et al., 1990; Sarkar et al., 1976). Throughout the remainder of the cycle, estradiol exerts negative feedback actions on the central reproductive axis. A direct role of estradiol on the GnRH neuron has been dismissed since Shivers et al (Shivers et al., 1983) reported a lack of ER immunoreactivity in GnRH neurons. However, there is a growing body of evidence demonstrating expression of functional estrogen receptors in GnRH neurons both from in vivo studies (Butler et al., 1999; Kallo et al., 2001; Hrabovszky et al., 2007; Hrabovszky et al., 2001), as well as from GnRH-expressing neuronal cells lines (Navarro et al., 2003; Poletti et al., 1994; Roy et al., 1999; Shen et al., 98 A.D.a). The mRNA obtained by Shen et al. from GT1-7 cells (Shen et al., 98 A.D.b) was sequenced and found to be estrogen receptor $\alpha$ $(\mathrm{ER} \alpha)$. These studies suggest that estrogen may exert a direct effect at the level of the GnRH neuron. In vitro evidence of direct negative estrogen regulation of rat GnRH gene expression include transfection studies in placental JEG-3 cells (Wierman 1992), and in GT1-7 GnRHexpressing neuronal cells co-transfected with ER (Kepa 1992). These in vitro studies indicate that estrogen decreases expression of the rat GnRH gene promoter. Studies of the human GnRH promoter in transient transfection experiments in JEG-3 cells co-transfected with ER $\alpha$ cDNA also indicate estrogen-mediated regulation of the human GnRH promoter (Radovick et al., 1991a; Dong et al., 1996). Studies performed by Roy et al. (Roy et al., 1999) demonstrated a decrease in GnRH mRNA levels in the GnRH expressing neuronal cell line, GT1-7 treated with $17 \beta$-estradiol over a 48 hour time course, starting as early as 12 hours.

Evidence regarding the effect of estrogen on $\mathrm{GnRH}$ gene expression remains more limited than the effects of estrogen on GnRH secretion. A post-mortem study in humans indicated that postmenopausal human females have significantly higher levels of GnRH mRNA levels compared with premenopausal women (Rance and Uswandi, 1996), suggesting that lack of estrogen in postmenopausal women might have contributed to the high GnRH mRNA levels observed. In vivo studies in several mammalian species have indicated that estrogen also reduces GnRH gene expression (Zoeller and Young, 1988; Petersen et al., 1995; Spratt and Herbison, 1997; Spratt and Herbison, 1997) and in vitro studies in hypothalamic rat explants (Wray et al., 1989) demonstrated an inhibitory effect of estrogen on GnRH mRNA expression. We have shown evidence of sex steroid, including estrogen and testosterone, modulation of $\mathrm{GnRH}$ gene expression in vivo in transgenic mice bearing a GnRH promoter driven luciferase reported construct (Wolfe et al., 1995).

In vivo immunoreactive studies to date (Herbison et al., 1995; Herbison and Theodosis, 1992; Herbison et al., 1993) have indicated that estrogen receptors are highly expressed in the hypothalamus, but in other neurons (Goldsmith et al., 1997) and glial-cells (Langub, Jr. and Watson, Jr., 1992) afferent to GnRH neurons rather than in GnRH neurons. For example, the bimodal effect in females appears, in part, to be mediated by anatomically distinct populations of kisspeptin neurons, with negative feedback regulation being controlled by kisspeptin neurons in the arcuate nucleus and positive feedback being regulated by kisspeptin neurons in the anteroventral periventricular nucleus (Dungan et al., 2006; Smith et al., 2006; Gottsch et al., 2006). These studies suggest that there is a strong indirect effect of estradiol on the regulation of GnRH neurons, but studies performed using GPR54 KO mice (GPR54 is the 
kisspeptin receptor) have shown that these mice retain the ability to generate $\mathrm{LH}$ surges (Dungan et al., 2007) suggesting that estrogen may regulate the GnRH neuron in multiple ways.

The role of progesterone and the progesterone receptor in the GnRH neuron has been controversial. It has been clearly demonstrated that progesterone secretion from the ovary coordinates LH surge generation (White et al., 2007; Chappell et al., 1999; Lydon et al., 1995) and reproductive behavior (Powers, 1970; Mani et al., 1994; Mani et al., 2006). Further, progesterone has also been shown to increase GnRH transcription in the hypothalamus (White et al., 2007) and progesterone receptors have been found on a subset of GnRH neurons in vivo (King et al., 1995). Estrogen has also been shown to induce progesterone receptor expression (Kaneko et al., 1993; Sanchez-Criado et al., 2004; Sanchez-Criado et al., 2005), thought to be important in mediating augmentation of the estradiol induced LH surge.

Two GnRH neuronal cell lines were used in these studies to examine the role of estradiol in the regulation of gene expression directly at the level of the GnRH neuron. Both the GN11 and GT1-7 cell lines were obtained by targeted transformation of GnRH neurons in transgenic mice using the small $\mathrm{T}$ antigen oncogene (Tag). These cell lines have been used as models of central GnRH neurons by a vast array of investigators (Anderson et al., 1999; Belsham et al., 1998; Besecke et al., 1994; Bruder and Wierman, 1994; Farkas et al., 2007; Gore et al., 1995; Kelley et al., 2000; Lawson et al., 1998; Maggi et al., 1995; Maggi et al., 2000; Magni et al., 1999; Martinez et al., 1992; Navarro et al., 2003; Weiner and Martinez, 1993).

These studies were designed to assess the effects of estradiol on the expression of GnRH, estrogen receptor $\alpha$ and $\beta$ and the progesterone receptor. We further sought to determine the isoform specificity of estradiol regulation.

\section{Materials and Methods \\ Cell Culture and Reagents}

GN11 cells were grown in Dulbecco modified Eagle medium (Cellgro, Hernden, VA) supplemented with 10\% fetal bovine serum (Hyclone, Logan, UT), 10mM L-glutamine (Invitrogen, Carlsbad, CA), and antibiotic/antimycotic (Invitrogen) and plated in $100 \mathrm{~mm} \times$ $20 \mathrm{~mm}$ cell culture dishes. GT1-7 cells were grown in a similar manner, except supplemented with $10 \%$ heat-inactivated fetal bovine serum. The following day, cells were washed with PBS and grown in Dulbecco modified Eagle medium without phenol red (Cellgro) and supplemented with $10 \%$ charcoal and resin stripped fetal bovine serum for 24 hours before treatment. Cells were treated with either 17ß-Estradiol (E2) (Sigma-Aldrich, St. Louis, MO), diarylpropionitrile (DPN) (Tocris Bioscience, Ellisville, MO), propyl-pyrazole-triol (PPT) (Tocris Bioscience), or ICI 182, 780 (Tocris Bioscience) for 16 hours before RNA extraction. Treatments were diluted in $100 \%$ ethanol to final concentrations of $1 \mathrm{nM}, 10 \mathrm{nM}$, and $100 \mathrm{nM}$, whereas control cells were treated with a comparable amount of ethanol.

\section{Receptor-binding assay}

The affinity of the binding sites in GN11 cells for estradiol was determined using a saturation radioligand binding assay. Cells were plated in six well plates and allowed to come to 70-90\% confluence. Cells were changed to a serum free media overnight (DMEM with high glucose, $4 \mathrm{mM}$ glutamine and antibiotic/antimycotic, both from Invitrogen). An ${ }^{125}$ I Estrogen Receptor Assay Kit (Rianen Assay System, NEN-Dupont, Wilmington, DE) was used to perform the assay. Cells were collected and incubated with 0.022 to $0.89 \mathrm{nM}$ of the radioligand overnight at $4^{\circ} \mathrm{C}$. Cells were incubated with charcoal suspensions for 15 minutes at $4^{\circ} \mathrm{C}$, centrifuged and supernatant collected and counted in a gamma counter (Cobra, Auto-Gamma, Packard Instruments, Downer's Grove, IL). The bound/unbound ratio was less than $10 \%$ for all 
radioligand concentrations. The counter efficiency was assessed to be $50 \%$. The specific bound (fmol/mL) was calculated for each tracer concentration and plotted versus the concentration of ligand. Results are derived from two separate assays performed in triplicate. Data was analyzed by non-linear regression analysis using GraphPad Prism (Version 5.0 for Windows, GraphPad Software, San Diego, CA). Kd and BMax assessed by non-linear regression analysis were then used to produce a Scatchard plot for visual display purposes.

\section{Standard Curve and Copy Number}

Mouse GnRH, mouse ER $\alpha$, and mouse ER $\beta$ cDNA obtained from a cloned plasmid was used to produce a standard curve by quantitative real-time PCR (qRT-PCR). Quantities ranging from $10^{-10}-10^{-15} \mathrm{~g}$ of each respective cDNA was used. Absolute copy number of standards was derived by dividing the molecular mass of the cDNA plasmid $(\mathrm{g} / \mathrm{mol})$ into the mass of each standard (g). These values were then multiplied by Avogadro's number $\left(\mathrm{mol}^{-1}\right)$ to derive a standard curve of threshold cycle vs. copy number. The copy number of transcripts in unknown PCR products were then determined from their $C_{\mathrm{t}}$ values on the standard curve.

\section{Quantitative Real-Time PCR}

Total RNA was obtained from GN11 and GT1-7 cells by Trizol (Invitrogen) extractions. Two micrograms of RNA was reverse transcribed (iScript cDNA Synthesis Kit, BioRad, Hercules, CA) to produce cDNA. cDNA representing 50ng of starting RNA was used in each reaction. $25 \mu \mathrm{L}$ of PCR reactions were performed using the IQ SybrGreen supermix (BioRad). Reactions were measured using the MyiQ quantitative real time PCR machine (BioRad). Primer sets for mouse GnRH (sense 5'-CCCTTTGACTTTCACATCC-3' and antisense 5'GGGTTCTGCCATTTGATCCAC-3'), ER $\alpha$ (sense 5'-CTTCAGTGCCAACAGCCT-3' and antisense 5'-GACAGTCTCTCTCGGCCAT-3'), ER $\beta$ (sense 5'GCCAACCTCCTGATGCTTCTTT-3' and antisense 5'TTGTACCCTCGAAGCGTGTGA-3') and a ribosomal 18 S control (sense 5'TGGTTGATCCTGCCAGTAG-3' and antisense 5'-CGACCAAAGGAACCATAACT-3') were used. Two isoforms of the PR have been identified, a longer PR-B and an N-terminally truncated PR-A. Primers amplifying both PR-A and PR-B were used (sense 5'GGTGGGCCTTCCTAACGAG-3' and antisense 5'-GACCACATCAGGCTCAATGCT-3'). To specifically identify PR-B mRNA levels, PR-B specific primers were used (sense 5'GGTCCCCCTTGCTTGCA-3' and antisense 5'-CAGGACCGAGGAAAAAGCAG-3'). PCR conditions were optimized to generate $>95 \%$ PCR efficiency and only those reactions between 95\% and $105 \%$ efficiency were included in subsequent analysis. Cycle threshold $\left(C_{\mathrm{t}}\right)$ was obtained for each sample. A corrected $C_{\mathrm{t}}\left(\Delta C_{\mathrm{t}}\right)$ was calculated by subtracting the $18 \mathrm{~S} C_{\mathrm{t}}$ from the unknown sample $C_{\mathrm{t}}$ for each sample. Relative differences from the control sample were then calculated by using the formula: fold change $=2^{\wedge}\left(\operatorname{control} \Delta C_{\mathrm{t}}\right.$ minus sample $\left.\Delta C_{\mathrm{t}}\right)$. PCR products were also analyzed by gel electrophoresis.

\section{GnRH Radioimmunoassay}

GN11 and GT1-7 cells were grown with media as previously mentioned, in 6 well plates with $1 \mathrm{~mL}$ of medium per well. The following day, cells were washed with PBS and grown in Dulbecco modified Eagle medium without phenol red (Cellgro) and supplemented with 10\% charcoal and resin stripped fetal bovine serum for 24 hours before treatment. Cells were then treated with 10nM E2 (Sigma-Aldrich), whereas control cells were treated with a comparable amount of ethanol. Medium was collected after 16 hours. Radioimmunoassay (RIA) for GnRH was performed at the Ligand Assay Core of the Baltimore-Chicago Cooperative Center in Reproductive Research at Northwestern University (Dr. Jon Levine, Director). The assay exhibits inter- and intra-assay coefficient of variation of less than $10 \%$. The lower limit of sensitivity of the assay is $0.1 \mathrm{pg} / 100 \mathrm{uL}$. 


\section{Statistics}

All quantitative RT-PCR studies were replicated at least three times with triplicate determination of each individual sample. ANOVA with Tukey's multiple comparison test for post-hoc analysis was used. A p value of $<0.05$ was required to assess significance. $T$ test was used to analyze secretion studies.

\section{Results}

\section{Radioligand Binding-Assays}

GN11 cells were studied for the presence of estrogen receptor (ER) using saturation binding analysis. A saturation binding curve was produced and analyzed by non-linear regression analysis to assess the BMax and binding affinity $(\mathrm{Kd})$. A Scatchard plot is provided as an inset. (Figure 1). The Kd value of $0.43 \mathrm{nM}$ is in the range of affinities determined for wild type ER in various other cell lines (Kuiper et al., 1997; Ince et al., 1993) including GT1-7 cells (Shen et al., 1998). Using the calculated Bmax of $11.75 \mathrm{fmol} / \mathrm{mL}, 5.4 \times 10^{9}$ receptors were present in the binding assay. For the $1.6 \times 10^{6}$ cells used in the experiment, it was calculated that there were 3375 receptors/cell.

\section{GnRH gene expression decreases in GnRH-secreting neurons treated with estradiol}

In order to demonstrate the effects of estrogen on mGnRH gene expression, GN11 and GT1-7 cells were plated and grown, then treated with 1,10 or $100 \mathrm{nM}$ E2 for 16 hours. Cells treated with only vehicle were used as a control. qRT-PCR of cellular RNA from treatments of each cell line was performed as described above. GnRH gene expression decreased by $50 \%$ and $75 \%$ in GN11 cells treated with $10 \mathrm{nM}$ and $100 \mathrm{nM}$ of E2, respectively (Figure 2A). GnRH gene expression decreased by $61 \%$, and $41 \%$ in GT1-7 cells treated with $10 \mathrm{nM}$ and $100 \mathrm{nM}$ of E2, respectively (Figure 2B). When ICI 182, 780 was added along with E2, GnRH expression levels in both cell lines returned to baseline levels. GnRH secretion was assessed from media obtained from static cultures. Sixteen hours of treatment with $10 \mathrm{nM}$ estradiol resulted in a significant decrease of $60 \%$ and $44 \%$ in GnRH secretion in GN11 and GT1-7 cells, respectively (Data not shown).

\section{GnRH gene expression decreases in GnRH-secreting neurons treated with estrogen receptor agonists}

In order to demonstrate the effects of estrogen receptor agonists on GnRH gene expression, GN11 and GT1-7 cells were plated and grown, then treated with 1, 10 or 100nM of the ER $\beta$ agonist (DPN) or ER $\alpha$ agonist (PPT) for 16 hours. Cells treated with only vehicle were used as a control. qRT-PCR of cellular RNA from treatments of each cell line was performed as described above. GnRH gene expression decreased by $15 \%$, 55\%, and 75\% in GN11 cells treated with $1 \mathrm{nM}, 10 \mathrm{nM}$, and $100 \mathrm{nM}$ of DPN, respectively. GnRH gene expression decreased by $73 \%$ in GN11 cells treated with $100 \mathrm{nM}$ of PPT (Figure 3A). GnRH gene expression decreased by $45 \%, 64 \%$, and $65 \%$ in GT1-7 cells treated with $1 \mathrm{nM}, 10 \mathrm{nM}$ and $100 \mathrm{nM}$ of DPN, respectively (Figure 3B). In contrast to GN11 cells, PPT did not decrease GnRH mRNA levels in GT1-7 cells (Figure 3B).

\section{GnRH-secreting cells express mGnRH, mERs and mPR}

RT-PCR of cellular RNA from GN11 and GT1-7 cell lines was performed using primers designed to amplify GnRH, ER $\alpha, E R \beta$, or PR. An agarose gel demonstrates the presence of $\mathrm{GnRH}, \mathrm{ER} \beta$, and PR in both cell lines. The presence of ER $\alpha$ is also detected in GN11 cells but not GT1-7 cells (Figure 4A). As a negative control, RNA that was not reverse transcribed was used. Expression levels of GnRH, ER $\alpha$ and ER $\beta$ from these cell lines were measured from a standard curve using known quantities of GnRH, ER $\alpha$, or ER $\beta$ cDNA contained in a plasmid. 
The data shown are represented as copy number derived from representative molar quantities (Figure 4B). GN11 cells express lower levels of GnRH than GT1-7 cells while expressing higher levels of both ER isoforms. ER $\alpha$ gene expression in GT1-7 cells was below the detection limit of the assay.

\section{ER gene expression decreases in GnRH-secreting neurons treated with estradiol}

In order to demonstrate the effects of estrogen on ER $\alpha$ and ER $\beta$ gene expression, GN11 and GT1-7 cells were plated and grown, then treated with varying concentrations of E2. Cells treated with only vehicle were used as a control. qRT-PCR of cellular RNA from treatments of each cell line was performed as described above. ER $\alpha$ gene expression decreased by $60 \%$ and ER $\beta$ gene expression decreased by $40 \%$ in GN11 cells treated with 100nM E2 (Figure 5A). ER $\beta$ gene expression decreased by $43 \%$ in GT1-7 cells treated with 100nM E2 (Figure 5B).

\section{ER gene expression decreases in GnRH-secreting neurons treated with estrogen receptor agonists}

In order to demonstrate the effects of estrogen receptor agonists on ER $\beta$ and ER $\alpha$ gene expression, GN11 and GT1-7 cells were plated and grown, then treated with 1, 10 or 100nM concentrations of ER $\beta$ agonist (DPN) or ER $\alpha$ agonist (PPT). Cells treated with only vehicle were used as a control. qRT-PCR of cellular RNA from treatments of each cell line was performed as described above. ER $\alpha$ gene expression decreased by $52 \%$ in GN11 cells treated with $100 \mathrm{nM}$ of DPN. The $10 \mathrm{nM}$ dose of DPN also reduced ER $\alpha$ gene expression by $31 \%$, but this did not achieve statistical significance. ER $\alpha$ gene expression decreased by 59\% in GN11 cells treated with $100 \mathrm{nM}$ of PPT. The $10 \mathrm{nM}$ dose of PPT also reduced the expression of ER $\alpha$ by $25 \%$, but this did not reach statistical significance. ER $\beta$ gene expression decreased by $59 \%$ in GN11 cells treated with 100nM of DPN. ER $\beta$ gene expression decreased by $67 \%$ in GN11 cells treated with 100nM of PPT (Figure 6A). ER $\beta$ gene expression decreased by $15 \%$, $27 \%$, and $45 \%$ in GT1-7 cells treated with $1 \mathrm{nM}, 10 \mathrm{nM}$, and 100nM of DPN, respectively (Figure 6B). While all three doses reduced ER $\beta$ expression, only the $100 \mathrm{nM}$ dose produced a statistically significant decrease.

\section{mPR gene expression increases in GnRH-secreting neurons treated with estradiol}

In order to demonstrate the effects of estrogen on mPR-AB and mPR-B gene expression, GN11 and GT1-7 cells were plated and grown, then treated with varying concentrations of E2. Cells treated with only vehicle were used as a control. qRT-PCR of cellular RNA from treatments of each cell line was performed as described above. mPR-AB gene expression increased 13.5 fold and mPR-B gene expression increased 15.5 fold in GN11 cells treated with 100nM of E2 (Figure 7A). mPR-AB and mPR-B gene expression increased 15.1 and 13.5 fold, respectively, in GT1-7 cells treated with 100nM of E2 (Figure 7B).

\section{mPR gene expression increases in GnRH-secreting neurons treated with estrogen receptor agonists}

To clarify the estrogen receptor isoform mediating the effects on PR-AB and mPR-B gene expression GN11 and GT1-7 cells were plated and grown, then treated with varying concentrations of ER $\beta$ agonist (DPN) or ER $\alpha$ agonist (PPT). Cells treated with only vehicle were used as a control. qRT-PCR of cellular RNA from treatments of each cell line was performed as described above. mPR-AB and mPR-B gene expression increased 12.4 and 11.1 fold, respectively, in GN11 cells treated with 100nM of DPN. mPR-AB and mPR-B gene expression also increased 11.8 and 10.1 fold, respectively, in GN11 cells treated with 100nM of PPT (Figure 7C). mPR-AB and mPR-B gene expression increased 14.1 and 10.0 fold, respectively, in GT1.7 cells treated with 100nM of DPN (Figure 7D). No significant increase was observed in GT1-7 cells treated with PPT. 


\section{Discussion}

Estrogen regulation of the hypothalamic-pituitary gonadal hormone axis is an essential aspect of both homeostatic regulation and the cyclic ovulatory cycle in females. Although there is likely an indirect component of estrogen regulation of the hypothalamic limb of the axis mediated by kisspeptinergic neurons and its cognate receptor, GPR54 (Gottsch et al., 2006; Seminara et al., 2003; Tena-Sempere, 2006) there is a wealth of recent evidence indicating that circulating estrogen may directly regulate the GnRH neuron (Roy et al., 1999; Poletti et al., 1994; Butler et al., 1999; Kallo et al., 2001; Skynner et al., 1999; Navarro et al., 2003).

The role of ER $\beta$ in neuronal function continues to be controversial. Abraham et al. studied $E R \alpha$ and $E R \beta$ knockout mice and showed that ER $\beta$ mediates the rapid, direct effects of estrogen on the GnRH neuron (Abraham et al., 2003). Wintermandel in 2005 demonstrated in elegant studies performed in a neuron specific knock out of ER $\alpha$ that $E R \alpha$ was critical for positive feedback regulation of the central reproductive axis (Wintermantel et al., 2006). A recent report from Antal et al 2008 reports that unlike previous studies, ER $\beta$ knockout mice generated in their laboratory using the cre-lox system and having no partial transcripts of ER $\beta$ were infertile (Antal et al., 2008). The level of infertility was not elucidated, however this study brings into question the results from the previous four knock out lines that demonstrate a subtle subfertile phenotype. The role of ER $\beta$ in central control of reproduction thus needs be studied in this model. The role of negative feedback, the level and mechanism of negative feedback will need to be dissected in these models.

In order to determine a direct effect of estradiol on regulation of $\mathrm{GnRH}$, we utilized two $\mathrm{GnRH}$ expressing neuronal cell lines. The GN11 cells were derived from an olfactory tumor from a mouse containing a transgene consisting of Tag under the regulatory control of $1131 \mathrm{bp}$ of the human GnRH promoter (Radovick et al., 1991b; Zhen et al., 1997). They are thought to be derived from GnRH neurons transformed early in development (Pimpinelli et al., 2003; Fang et al., 1998; Maggi et al., 2000). The GT1-7 cells were derived from an hypothalamic tumor from a mouse containing a transgene consisting of Tag under the regulatory control of a rat promoter fragment (Mellon et al., 1990). These cells are thought to represent a more mature cell as they were transformed at a later developmental age (Pimpinelli et al., 2003; Fang et al., 1998; Maggi et al., 2000). This is the first report documenting the relative expression of the estrogen receptors in the different $\mathrm{GnRH}$ expressing cell lines and their contributions to $\mathrm{GnRH}$ gene expression and secretion.

In order to determine whether functional estrogen receptors are expressed in GnRH neuronal cell lines, we elected to perform in vitro studies using the reported GN11 and GT1-7 cell lines. Structurally intact estrogen receptors in GN11 cells were confirmed by use of a radioligand binding assay. We demonstrated binding of $17 \beta$-estradiol to ER with a dissociation constant of $0.43 \mathrm{nM}$ (Figure 1), compatible with previously published ER dissociation constants in other cells (Ince et al., 1993;Kuiper et al., 1997) and in GT1-7 cells (Shen et al., 1998).

Previous studies using GT1-7 cells had identified ER $\alpha$ (Shen et al., 1998; Butler et al., 1999), ER $\beta$ (Kallo et al., 2001) or both ER $\alpha$ and ER $\beta$ expression (Navarro et al., 2003; Roy et al., 1999). These varied observations might reflect differences in cell culture phenotype of GT1-7 cells in different investigator's laboratories or to differences in detection methods. A similar lack of consensus exists in studies performed in vivo or in hypothalamic tissue explants (Legan and Tsai, 2003; Temple et al., 2004; Hrabovszky et al., 2007; Hrabovszky et al., 2001; Herbison et al., 2001; Butler et al., 1999). These differences may be due to heterogeneity of gene expression in the GnRH neuron population or might reflect regulation of gene expression of ER by the hormonal environment. 
Our studies have demonstrated that both ER isoforms were present in the GN11 cells and primarily ER $\beta$ was present in the GT1-7 cell line in our laboratory (Figure 4). Absolute numbers of ER transcripts were calculated by quantitative real-time PCR (Figure 4B) and both ER $\alpha$ and ER $\beta$ were determined to be more abundantly expressed in GN11 cells than in GT1-7 cells. Additionally, ER $\alpha$ was expressed below the limit of detectability of our PCR assays in GT1-7 cells, although ER $\beta$ was expressed at relatively high levels (Figure 4). This is correlated with an effect of only the $\beta$ agonist (DPN) in GT1-7 cells and the effect of both $\alpha$ (PPT) and $\beta$ (DPN) agonists in GN11 cells.

Studies by Sharifi et al. have used GnRH neurons obtained from 11.5 day embryos and maintained in culture for up to 28 days to determined ER expression patterns (Sharifi et al., 2002). They found ER $\beta$, but not ER $\alpha$ to be expressed in the cells at all time points studied, however the number of cells expressing ER $\beta$ decreased over time. This is in disagreement with our study and others (Navarro et al., 2003; Roy et al., 1999; Titolo et al., 2008; Titolo et al., 2006; Martinez-Morales et al., 2001a; Martinez-Morales et al., 2001b) that have shown expression of ER $\beta$ in the mature GT1-7 cell line and the current manuscript demonstrating expression of ER $\alpha$ in GN cells). Adding to the controversy, a recent study by Hu et al showed that rat fetal and adult GnRH neurons express both ER $\alpha$ and ER $\beta$ and that GT1-7 cells also express both forms of the ER (Hu et al., 2008). Interestingly, this study shows that expression of ER varies with estrous cycle and that high estradiol levels, both in vitro and in vivo during proestrous are associated with decreasing ER expression. The explanation for these differences is unknown, although different model systems have been used, the culture conditions varied and the methods used to determine the presence of ERs was varied.

The mechanism of estrogen down regulation of GnRH gene expression remains to be established. Estrogen is generally thought of as a positive regulator of gene transcription, acting through the classic estrogen receptor signaling pathway. Indeed, positive regulation of PR gene expression by estradiol in both GN11 and GT1-7 cells was seen (Figure 7A and B). However, there is also a growing body of evidence indicating a role for estrogen-mediated negative regulation of gene expression. In addition to negative regulation of mouse (Figure 2 and 3), rat (Wierman et al., 1992) and human (Chen et al., 2001; Dong et al., 1996) GnRH gene expression by estrogen, negative regulation of a number of other target genes by estrogen has been reported. These genes include the Interleukin-6 promoter (Stein and Yang, 1995) in human osteoblast cells, the apoA1 promoter in human hepatoma HepG2 cells (Harnish et al., 1998), and the Gata-1, SC1-1 and globin gene promoters in avian erythroid precursor cells (von Lindern et al., 1998). An exploration of the estrogen receptor isoform specificity of this effect indicated that activation of either ER $\alpha$ or ER $\beta$ with PPT or DPN, respectively, stimulated expression of PR. In GT1-7 cells, in contrast, only activation of ER $\beta$ with DPN stimulated PR expression. These data provide further confirmatory evidence for the presence of both ER $\alpha$ and ER $\beta$ in GN11 cells and specifically ER $\beta$ in GT1-7 cells.

The negative estrogen signaling pathway involves estrogen-dependent activation of ER, but may not involve binding of the estrogen-ER complex to DNA-response elements in the promoter region of target genes (von Lindern et al., 1998; Harnish et al., 1998; Stein and Yang, 1995; Wierman et al., 1992). In fact, genes that are negatively regulated by estrogen appear to lack an identifiable estrogen-response element (ERE) in their respective promoter regions, which includes the promoter region of the rat and mouse GnRH gene. The human GnRH gene promoter includes an ERE site sharing 80\% homology with the consensus Xenopus vitellogenin ERE, which may mediate a positive ER response (Chen et al., 2001). The mechanism of negative regulation of the human GnRH promoter by estrogen has not been established (Chen et al., 2001; Dong et al., 1996), but it also appears to be regulated in an indirect manner (Chen et al., 2001). 
Although several studies have demonstrated the presence of ER $\beta$ in GnRH neurons, their physiological role is not clear. Antagonists of ER $\beta$, used in vivo, have been shown to not compromise the generation of the LH surge, but rather to enhance the acute response to kisspeptin stimulation. This effect may be mediated by ER $\beta$ expressed in GnRH neurons or their afferents, as suggested by the authors (Roa et al., 2008). This is in agreement with our data, showing negative effects of agonist bound ERb on GnRH gene expression.

In our studies, estradiol also decreased GnRH secretion from GN11 and GT1-7 cells. Nearly $50 \%$ less GnRH was measured in the media of cells treated with $10 \mathrm{nM}$ estradiol for 16 hours. Whether this effect is mediated by classic estrogen receptor signaling or in response to activation of a membrane estrogen receptor is unclear. Previous work by Navarro et al. (Navarro et al., 2003), however, suggested that effects of estradiol on the regulation of cAMP accumulation, and thus secretion might be regulated by estradiol effects at the membrane level. In these studies, picomolar doses of estradiol inhibited cAMP accumulation as well as stimulating secretion in a static culture paradigm designed to mimic the estrous cycle hormonal milieu. Nanomolar levels of estradiol, in contrast, stimulated accumulation of cAMP. Effects of nanomolar doses of estradiol on secretion were not examined in this study, but based on the biphasic response of cAMP levels to estradiol, it might be inferred that nanomolar doses might have resulted in suppression of secretion as we report.

Another member of the nuclear hormone receptor family, the glucocorticoid receptor, has also been shown to exert its effect indirectly via interactions with other transcription factors (YangYen et al., 1990; Heck et al., 1994; Chandran et al., 1996; Chandran et al., 1999), including on the human GnRH promoter (Chandran et al., 1996; Chandran et al., 1999). Conversely, negative regulation of gene expression by nuclear receptors has also been shown to involve binding to non-consensus DNA-response sites. This mechanism of action was described in studies of progesterone down regulation of the rat GnRH promoter (Kepa et al., 1996). Interestingly, a mutant mouse model produced by knocking in an ER $\alpha$ allele unable to positively regulate on an ERE due to a disruption of the first zinc finger in the DNA binding domain, was found to be infertile (Glidewell-Kenney et al., 2007). These mice retain estrogen negative feedback on LH secretion, but were unable to induce estrogen positive feedback to induce an LH surge. These results support a classic mechanism of ERE mediated regulation underlying estrogen positive feedback and a non-classical mechanism underlying estrogen negative feedback.

In addition to its direct role in mediating GnRH gene expression, whether by classical or nonclassical mechanisms, estradiol also was shown to increase expression of the PR in both cell lines (Figures 7A and B). Progesterone receptors have been found in a subset of guinea pig GnRH neurons in vivo (King et al., 1995), raising the possibility of a direct role in cellular function. Progesterone plays an important role in the regulation of the reproductive hormone axis - both positive (Bauer-Dantoin et al., 1993; White et al., 2007; Attardi et al., 2007) and negative (Skinner et al., 1998; Attardi et al., 2007; Bauer-Dantoin et al., 1995) feedback - as well as with coordinating reproductive behaviors (White et al., 2007; Lydon et al., 1995). However, a direct role for progesterone at the level of the GnRH neuron in feedback regulation has not been demonstrated. Although initial studies did not identify progesterone receptors in GnRH neurons in rats (Fox et al., 1990), progesterone has been reported to exert regulatory effects at the level of the GnRH neuronal cell lines in studies performed in GT1-7 cells transfected with a PR expression vector (Navarro et al., 2003). These previous studies, performed in steroid depleted media, may have been unable to document the presence of PR; hence explaining the identifiable PR expression. This is consistent with our results showing estradiol induction of PR expression. 
Estrogen also has been shown to regulate ER and PR expression, providing an additional mechanism by which estrogen can exert complex regulatory effects. For example, Rune et al. observed an increase in ER $\alpha$ levels in the hippocampus in response to E2 treatment (Rune et al., 2002) whereas Read et al. noted a cell line specific and serum dependent response of ER levels to E2 (Read et al., 1989). E2 has been shown to stimulate PR gene expression in a variety of cells and tissues including breast cancer cells (Cho et al., 1994), uterus (Aronica and Katzenellenbogen, 1991) and brain (Mani et al., 1994). Our studies confirm that estradiol regulates ER $\alpha, E R \beta$ (Figures 5 and 6) and PR gene expression (Figure 7) in GnRH neuronal cell lines.

In conclusion, we have shown evidence of functional estrogen receptors in GnRH neuronal cell lines and have shown that estrogen down regulates GnRH gene expression in vitro. The GN11 and GT1-7 cell lines provide models for the study of both estrogen receptor mediated negative regulation (GnRH and ER) and positive regulation (PR) in the same cell.

\section{Acknowledgements}

This research was supported by NICHD/NIH through cooperative agreement [U54 HD 933067 (The BaltimoreChicago Center for Reproductive Research)] as part of the Specialized Cooperative Centers Program in Reproduction and Infertility Research (SCCPIR). The authors would also like to thank George Park and Dan Diaczok for manuscript review.

\section{Reference List}

Abraham IM, Han SK, Todman MG, Korach KS, Herbison AE. Estrogen receptor beta mediates rapid estrogen actions on gonadotropin-releasing hormone neurons in vivo. J Neurosci 2003;23:5771-5777. [PubMed: 12843281]

Anderson RA, Zwain IH, Arroyo A, Mellon PL, Yen SS. The insulin-like growth factor system in the GT1-7 GnRH neuronal cell line. Neuroendocrinology 1999;70:353-359. [PubMed: 10567861]

Antal MC, Krust A, Chambon P, Mark M. Sterility and absence of histopathological defects in nonreproductive organs of a mouse ERbeta-null mutant. Proc Natl Acad Sci U S A 2008;105:24332438. [PubMed: 18268329]

Aronica SM, Katzenellenbogen BS. Progesterone receptor regulation in uterine cells: stimulation by estrogen, cyclic adenosine 3',5'-monophosphate, and insulin-like growth factor I and suppression by antiestrogens and protein kinase inhibitors. Endocrinology 1991;128:2045-2052. [PubMed: 1706263]

Attardi B, Scott R, Pfaff D, Fink G. Facilitation or inhibition of the oestradiol-induced gonadotrophin surge in the immature female rat by progesterone: effects on pituitary responsiveness to gonadotrophinreleasing hormone $(\mathrm{GnRH})$, GnRH self-priming and pituitary mRNAs for the progesterone receptor A and B isoforms. J Neuroendocrinol 2007;19:988-1000. [PubMed: 18001329]

Bauer-Dantoin AC, Tabesh B, Norgle JR, Levine JE. RU486 administration blocks neuropeptide Y potentiation of luteinizing hormone (LH)-releasing hormone-induced LH surges in proestrous rats. Endocrinology 1993;133:2418-2423. [PubMed: 8243259]

Bauer-Dantoin AC, Weiss J, Jameson JL. Roles of estrogen, progesterone, and gonadotropin-releasing hormone $(\mathrm{GnRH})$ in the control of pituitary $\mathrm{GnRH}$ receptor gene expression at the time of the preovulatory gonadotropin surges. Endocrinology 1995;136(3):1014-1019. [PubMed: 7867555]

Belsham DD, Evangelou A, Roy D, Duc VL, Brown TJ. Regulation of gonadotropin-releasing hormone $(\mathrm{GnRH})$ gene expression by 5alpha-dihydrotestosterone in GnRH-secreting GT1-7 hypothalamic neurons. Endocrinology 1998;139:1108-1114. [PubMed: 9492044]

Besecke LM, Wolfe AM, Pierce ME, Takahashi JS, Levine JE. Neuropeptide Y stimulates luteinizing hormone-releasing hormone release from superfused hypothalamic GT1-7 cells. Endocrinology 1994;135:1621-1627. [PubMed: 7925125]

Bruder JM, Wierman ME. Evidence for transcriptional inhibition of GnRH gene expression by phorbol ester at a proximal promoter region. Mol Cell Endo 1994;99:177-182. 
Butler JA, Sjoberg M, Coen CW. Evidence for oestrogen receptor alpha-immunoreactivity in gonadotrophin-releasing hormone-expressing neurones. J Neuroendocrinol 1999;11:331-335. [PubMed: 10320559]

Caraty A, Locatelli A, Martin GB. Biphasic response in the secretion of gonadotrophin-releasing hormone in ovariectomized ewes injected with oestradiol. J Endocrinol 1989;123:375-382. [PubMed: 2691622]

Chandran UR, Attardi B, Friedman R, Zheng Z, Roberts JL, DeFranco DB. Glucocorticoid repression of the mouse gonadotropin-releasing hormone gene is mediated by promoter elements that are recognized by heteromeric complexes containing glucocorticoid receptor. Journal of Biological Chemistry 1996;271:20412-20420. [PubMed: 8702778]

Chandran UR, Warren BS, Baumann CT, Hager GL, DeFranco DB. The glucocorticoid receptor is tethered to DNA-bound Oct-1 at the mouse gonadotropin-releasing hormone distal negative glucocorticoid response element. J Biol Chem 1999;274:2372-2378. [PubMed: 9891005]

Chappell PE, Schneider JS, Kim P, Xu M, Lydon JP, O'Malley BW, Levine JE. Absence of gonadotropin surges and gonadotropin-releasing hormone self-priming in ovariectomized (OVX), estrogen (E2)treated, progesterone receptor knockout (PRKO) mice. Endocrinology 1999;140:3653-3658. [PubMed: 10433223]

Chen Z, Zheng H, Dong KW. Identification of negative and positive estrogen response elements in human GnRH upstream promoter in the placental JEG-3 cells. Mol Cell Endocrinol 2001;184:125-134. [PubMed: 11694348]

Cho H, Aronica SM, Katzenellenbogen BS. Regulation of progesterone receptor gene expression in MCF-7 breast cancer cells: a comparison of the effects of cyclic adenosine 3',5'-monophosphate, estradiol, insulin-like growth factor-I, and serum factors. Endocrinology 1994;134:658-664. [PubMed: 7507831]

Chongthammakun S, Terasawa E. Negative feedback effects of estrogen on luteinizing hormonereleasing hormone release occur in pubertal, but not prepubertal, ovariectomized female rhesus monkeys. Endocrinology 1993;132:735-743. [PubMed: 8425492]

Dong KW, Chen ZG, Cheng KW, Yu KL. Evidence for estrogen receptor-mediated regulation of human gonadotropin-releasing hormone promoter activity in human placental cells. Mol Cell Endocrinol 1996;117:241-246. [PubMed: 8737386]

Dungan HM, Clifton DK, Steiner RA. Minireview: kisspeptin neurons as central processors in the regulation of gonadotropin-releasing hormone secretion. Endocrinology 2006;147:1154-1158. [PubMed: 16373418]

Dungan HM, Gottsch ML, Zeng H, Gragerov A, Bergmann JE, Vassilatis DK, Clifton DK, Steiner RA. The role of kisspeptin-GPR54 signaling in the tonic regulation and surge release of gonadotropinreleasing hormone/luteinizing hormone. J Neurosci 2007;27:12088-12095. [PubMed: 17978050]

Evans NP, Dahl GE, Glover BH, Karsch FJ. Central regulation of pulsatile gonadotropin-releasing hormone $(\mathrm{GnRH})$ secretion by estradiol during the period leading up to the preovulatory GnRH surge in the ewe. Endocrinology 1994;134:1806-1811. [PubMed: 8137746]

Evans NP, Dahl GE, Mauger D, Karsch FJ. Estradiol induces both qualitative and quantitative changes in the pattern of gonadotropin-releasing hormone secretion during the presurge period in the ewe. Endocrinology 1995;136:1603-1609. [PubMed: 7895670]

Fang Z, Xiong X, James A, Gordon DF, Wierman ME. Identification of novel factors that regulate GnRH gene expression and neuronal migration. Endocrinology 1998;139:3654-3657. [PubMed: 9681520]

Farkas I, Varju P, Liposits Z. Estrogen modulates potassium currents and expression of the Kv4.2 subunit in GT1-7 cells. Neurochem Int 2007;50:619-627. [PubMed: 17258352]

Fox SR, Harlan RE, Shivers BD, Pfaff DW. Chemical characterization of neuroendocrine targets for progesterone in the female rat brain and pituitary. Neuroendocrinology 1990;51:276-283. [PubMed: 1970131]

Glidewell-Kenney C, Hurley LA, Pfaff L, Weiss J, Levine JE, Jameson JL. Nonclassical estrogen receptor alpha signaling mediates negative feedback in the female mouse reproductive axis. Proc Natl Acad Sci U S A 2007;104:8173-8177. [PubMed: 17470805] 
Goldsmith PC, Boggan JE, Thind KK. Estrogen and progesterone receptor expression in neuroendocrine and related neurons of the pubertal female monkey hypothalamus. Neuroendocrinology 1997;65:325-334. [PubMed: 9158064]

Gore AC, Ho A, Roberts JL. Translational efficiency of gonadotropin-releasing hormone messenger ribonucleic acid is negatively regulated by phorbol ester in GT1-7 cells. Endocrinology 1995;136:1620-1625. [PubMed: 7895672]

Gottsch ML, Clifton DK, Steiner RA. Kisspepeptin-GPR54 signaling in the neuroendocrine reproductive axis. Mol Cell Endocrinol 2006:254-255. 91-96.

Harnish DC, Evans MJ, Scicchitano MS, Bhat RA, Karathanasis SK. Estrogen regulation of the apolipoprotein AI gene promoter through transcription cofactor sharing. J Biol Chem 1998;273:9270-9278. [PubMed: 9535920]

Heck S, Kullmann M, Gast A, Ponta H, Rahmsdorf HJ, Herrlich P, Cato AC. A distinct modulating domain in glucocorticoid receptor monomers in the repression of activity of the transcription factor AP-1. EMBO J 1994;13:4087-4095. [PubMed: 8076604]

Herbison AE, Horvath TL, Naftolin F, Leranth C. Distribution of estrogen receptor-immunoreactive cells in monkey hypothalamus: relationship to neurones containing luteinizing hormone-releasing hormone and tyrosine hydroxylase. Neuroendocrinology 1995;61:1-10. [PubMed: 7731492]

Herbison AE, Robinson JE, Skinner DC. Distribution of estrogen receptor-immunoreactive cells in the preoptic area of the ewe: co-localization with glutamic acid decarboxylase but not luteinizing hormone-releasing hormone. Neuroendocrinology 1993;57:751-759. [PubMed: 8367037]

Herbison AE, Skynner MJ, Sim JA. Erratum to 1999 Detection of estrogen receptor a and $\beta$ messenger ribonucleic acids in adult gonadotropin-releasing hormone neurons. Endocrinology 2001;142:492493.

Herbison AE, Theodosis DT. Localization of oestrogen receptors in preoptic neurons containing neurotensin but not tyrosine hydroxylase, cholecystokinin or luteinizing hormone-releasing hormone in the male and female rat. Neuroscience 1992;50:283-298. [PubMed: 1359459]

Hrabovszky E, Kallo I, Szlavik N, Keller E, Merchenthaler I, Liposits ZS. Gonadotropin-releasing hormone neurons express estrogen receptor-\{beta\}. J Clin Endocrinol Metab 2007;92:2827-2830. [PubMed: 17456575]

Hrabovszky E, Steinhauser A, Barabas K, Shughrue PJ, Petersen SL, Merchenthaler I, Liposits Z. Estrogen receptor-beta immunoreactivity in luteinizing hormone-releasing hormone neurons of the rat brain. Endocrinology 2001;142:3261-3264. [PubMed: 11416051]

Hu L, Gustofson RL, Feng H, Leung PK, Mores N, Krsmanovic LZ, Catt KJ. Converse regulatory functions of estrogen receptor-\{alpha $\}$ and - $\{$ beta $\}$ subtypes expressed in hypothalamic GnRH neurons. Mol Endocrinol. 2008

Ince BA, Zhuang Y, Wrenn CK, Shapiro DJ, Katzenellenbogen BS. Powerful dominant negative mutants of the human estrogen receptor. J Biol Chem 1993;268:14026-14032. [PubMed: 8314770]

Kallo I, Butler JA, Barkovics-Kallo M, Goubillon ML, Coen CW. Oestrogen receptor betaimmunoreactivity in gonadotropin releasing hormone-expressing neurones: regulation by oestrogen. J Neuroendocrinol 2001;13:741-748. [PubMed: 11578523]

Kaneko KJ, Gelinas C, Gorski J. Activation of the silent progesterone receptor gene by ectopic expression of estrogen receptors in a rat fibroblast cell line. Biochemistry 1993;32:8348-8359. [PubMed: 8347631]

Kelley CG, Lavorgna G, Clark ME, Boncinelli E, Mellon PL. The Otx2 homeoprotein regulates expression from the gonadotropin- releasing hormone proximal promoter. Mol Endocrinol 2000;14:1246-1256. [PubMed: 10935548]

Kepa JK, Jacobsen BM, Boen EA, Prendergast P, Edwards DP, Takimoto G, Wierman ME. Direct binding of progesterone receptor to nonconsensus DNA sequences represses rat GnRH. Mol Cell Endocrinol 1996;117:27-39. [PubMed: 8734471]

King JC, Tai DW, Hanna IK, Pfeiffer A, Haas P, Ronsheim PM, Mitchell SC, Turcotte JC, Blaustein JD. A subgroup of LHRH neurons in guinea pigs with progestin receptors is centrally positioned within the total population of LHRH neurons. Neuroendocrinology 1995;61:265-275. [PubMed: 7898631] 
Kuiper GG, Carlsson B, Grandien K, Enmark E, Haggblad J, Nilsson S, Gustafsson JA. Comparison of the ligand binding specificity and transcript tissue distribution of estrogen receptors alpha and beta. Endocrinology 1997;138:863-870. [PubMed: 9048584]

Langub MC Jr, Watson RE Jr. Estrogen receptor-immunoreactive glia, endothelia, and ependyma in guinea pig preoptic area and median eminence: electron microscopy. Endocrinology 1992;130:364372. [PubMed: 1727710]

Lawson MA, Buhain AR, Jovenal JC, Mellon PL. Multiple factors interacting at the GATA sites of the gonadotropin- releasing hormone neuron-specific enhancer regulate gene expression. Mol Endocrinol 1998;12:364-377. [PubMed: 9514154]

Legan SJ, Tsai HW. Oestrogen receptor-alpha and -beta immunoreactivity in gonadotropin-releasing hormone neurones after ovariectomy and chronic exposure to oestradiol. J Neuroendocrinol 2003;15:1164-1170. [PubMed: 14636178]

Levine JE, Ramirez VD. In Vivo Release of Luteinizing Hormone-Releasing Hormone Estimated with Push-Pull Cannulae from the Mediabasal Hypothalami of Ovariectomized, Steroid-Primed Rats. Endocrinology 1980;107:1782-1790. [PubMed: 7000501]

Lydon JP, DeMayo FJ, Funk CR, Mani SK, Hughes AR, Montgomery CA Jr, Shyamala G, Conneely OM, O'Malley BW. Mice lacking progesterone receptor exhibit pleiotropic reproductive abnormalities. Genes Dev 1995;9:2266-2278. [PubMed: 7557380]

Maggi R, Pimpinelli F, Martini L, Piva F. Characterization of functional opioid delta receptors in a luteinizing hormone-releasing hormone-producing neuronal cell line. Endocrinology 1995;136(1): 289-295. [PubMed: 7828543]

Maggi R, Pimpinelli F, Molteni L, Milani M, Martini L, Piva F. Immortalized luteinizing hormonereleasing hormone neurons show a different migratory activity in vitro. Endocrinology 2000;141:2105-2112. [PubMed: 10830297]

Magni P, Vettor R, Pagano C, Calcagno A, Beretta E, Messi E, Zanisi M, Martini L, Motta M. Expression of a leptin receptor in immortalized gonadotropin-releasing hormone-secreting neurons. Endocrinology 1999;140:1581-1585. [PubMed: 10098491]

Mani SK, Blaustein JD, Allen JM, Law SW, O'Malley BW, Clark JH. Inhibition of rat sexual behavior by antisense oligonucleotides to the progesterone receptor. Endocrinology 1994;135:1409-1414. [PubMed: 7925102]

Mani SK, Reyna AM, Chen JZ, Mulac-Jericevic B, Conneely OM. Differential response of progesterone receptor isoforms in hormone-dependent and -independent facilitation of female sexual receptivity. Mol Endocrinol 2006;20:1322-1332. [PubMed: 16484336]

Martinez, dIE.; Choi, AL.; Weiner, RI. Generation and synchronization of gonadotropin-releasing hormone (GnRH) pulses: intrinsic properties of the GT1-1 GnRH neuronal cell line. Proc Natl Acad Sci U S A 1992;89:1852-1855. [PubMed: 1542682]

Martinez-Morales JR, Lopez-Coviella I, Hernandez-Jimenez JG, Reyes R, Bello AR, Hernandez G, Blusztajn JK, Alonso R. Sex steroids modulate luteinizing hormone-releasing hormone secretion in a cholinergic cell line from the basal forebrain. Neuroscience 2001a;103:1025-1031. [PubMed: 11301209]

Martinez-Morales JR, Morales A, Marin R, Hernandez-Jimenez JG, Acevedo A, Guerra B, Hernandez G, Lopez-Coviella I, Prieto L, Alonso R. Estrogen modulates norepinephrine-induced accumulation of adenosine cyclic monophosphate in a subpopulation of immortalized luteinizing hormonereleasing hormone secreting neurons from the mouse hypothalamus. Neurosci Lett 2001b;298:6164. [PubMed: 11154836]

Mellon PL, Windle JJ, Goldsmith PC, Padula CA, Roberts JL, Weiner RI. Immortalization of Hypothalamic GnRH Neurons by Genetically Targeted Tumorigenesis. Neuron 1990;5:1-10. [PubMed: 2196069]

Moenter SM, Caraty A, Karsch FJ. The estradiol-induced surge of gonadotropin-releasing hormone in the ewe. Endocrinology 1990;127:1375-1384. [PubMed: 2201536]

Navarro CE, Saeed SA, Murdock C, Martinez-Fuentes AJ, Arora KK, Krsmanovic LZ, Catt KJ. Regulation of cyclic adenosine 3',5'- monophosphate signaling and pulsatile neurosecretion by Gicoupled plasma membrane estrogen receptors in immortalized gonadotrophin-releasing hormone neurons. Mol Endocrinol 2003;17:1792-1804. 
Petersen SL, McCrone S, Keller M, Shores S. Effects of estrogen and progesterone on luteinizing hormone-releasing hormone messenger ribonucleic acid levels: consideration of temporal and neuroanatomical variables. Endocrinology 1995;136:3604-3610. [PubMed: 7628399]

Pimpinelli F, Redaelli E, Restano-Cassulini R, Curia G, Giacobini P, Cariboni A, Wanke E, Bondiolotti GP, Piva F, Maggi R. Depolarization differentially affects the secretory and migratory properties of two cell lines of immortalized luteinizing hormone-releasing hormone (LHRH) neurons. Eur J Neurosci 2003;18:1410-1418. [PubMed: 14511321]

Poletti A, Melcangi RC, Negri-Cesi P, Maggi R, Martini L. Steroid binding and metabolism in the luteinizing hormone- releasing hormone-producing neuronal cell line GT1-1. Endocrinology 1994;135(6):2623-2628. [PubMed: 7988451]

Powers JB. Hormonal control of sexual receptivity during the estrous cycle of the rat. Physiol Behav 1970;5:831-835. [PubMed: 5535480]

Radovick S, Ticknor CM, Nakayama Y, Notides AC, Rahman A, Weintraub BD, Cutler GB Jr, Wondisford FE. Evidence for direct estrogen regulation of the human gonadotropin-releasing hormone gene. J Clin Invest 1991a;88:1649-1655. [PubMed: 1939651]

Radovick S, Wray S, Lee E, Nicols DK, Nakayama Y, Weintraub BD, Westphal H, Cutler GB Jr, Wondisford FE. Migratory arrest of gonadotropin-releasing hormone neurons in transgenic mice. Proc Natl Acad Sci USA 1991b;88:3402-3406. [PubMed: 2014260]

Rance NE, Uswandi SV. Gonadotropin-releasing hormone gene expression is increased in the medial basal hypothalamus of postmenopausal women. J Clin Endocrinol Metab 1996;81:3540-3546. [PubMed: 8855798]

Read LD, Greene GL, Katzenellenbogen BS. Regulation of estrogen receptor messenger ribonucleic acid and protein levels in human breast cancer cell lines by sex steroid hormones, their antagonists, and growth factors. Mol Endocrinol 1989;3:295-304. [PubMed: 2785242]

Roa J, Vigo E, Castellano JM, Gaytan F, Navarro VM, Aguilar E, Dijcks FA, Ederveen AG, Pinilla L, van Noort PI, Tena-Sempere M. Opposite roles of estrogen receptor (ER)-alpha and ERbeta in the modulation of luteinizing hormone responses to kisspeptin in the female rat: implications for the generation of the preovulatory surge. Endocrinology 2008;149:1627-1637. [PubMed: 18174277]

Roy D, Angelini NL, Belsham DD. Estrogen directly respresses gonadotropin-releasing hormone $(\mathrm{GnRH})$ gene expression in estrogen receptor-alpha (ERalpha)- and ERbeta-expressing GT1-7 GnRH neurons. Endocrinology 1999;140:5045-5053. [PubMed: 10537130]

Rune GM, Wehrenberg U, Prange-Kiel J, Zhou L, Adelmann G, Frotscher M. Estrogen up-regulates estrogen receptor alpha and synaptophysin in slice cultures of rat hippocampus. Neuroscience 2002;113:167-175. [PubMed: 12123695]

Sanchez-Criado JE, de Las Mulas JM, Bellido C, Aguilar R, Garrido-Gracia JC. Gonadotrope oestrogen receptor-alpha and -beta and progesterone receptor immunoreactivity after ovariectomy and exposure to oestradiol benzoate, tamoxifen or raloxifene in the rat: correlation with LH secretion. J Endocrinol 2005;184:59-68. [PubMed: 15642783]

Sanchez-Criado JE, Martin de Las MJ, Bellido C, Tena-Sempere M, Aguilar R, Blanco A. Biological role of pituitary estrogen receptors ERalpha and ERbeta on progesterone receptor expression and action and on gonadotropin and prolactin secretion in the rat. Neuroendocrinology 2004;79:247-258. [PubMed: 15205556]

Sarkar DK, Chiappa SA, Fink G, Sherwood NM. Gonadotropin-releasing hormone surge in pro-oestrous rats. Nature 1976;264:461-463. [PubMed: 794737]

Sarkar DK, Fink G. Luteinizing hormone releasing factor in pituitary stalk plasma from long-term ovariectomized rats: effects of steroids. J Endocrinol 1980;86:511-524. [PubMed: 7000953]

Seminara SB, Messager S, Chatzidaki EE, Thresher RR, Acierno JS Jr, Shagoury JK, Bo-Abbas Y, Kuohung W, Schwinof KM, Hendrick AG, Zahn D, Dixon J, Kaiser UB, Slaugenhaupt SA, Gusella JF, O'Rahilly S, Carlton MB, Crowley WF Jr, Aparicio SA, Colledge WH. The GPR54 gene as a regulator of puberty. N Engl J Med 2003;349:1614-1627. [PubMed: 14573733]

Sharifi N, Reuss AE, Wray S. Prenatal LHRH neurons in nasal explant cultures express estrogen receptor beta transcript. Endocrinology 2002;143:2503-2507. [PubMed: 12072381]

Shen ES, Meade EH, Perez MC, Deecher DC, Negro-Vilar A, Lopez FJ. Expression of functional estrogen receptors and galanin messenger ribonucleic acid in immortalized luteinizing hormone-releasing 
hormone neurons: estrogenic control of galanin gene expression. Endocrinology 1998 Mar;139:939948. [PubMed: 9492023]98 A.D.b

Shen ES, Meade EH, Perez MC, Deecher DC, Negro-Vilar A, Lopez FJ. Expression of functional estrogen receptors and galanin messenger ribonucleic acid in immortalized luteinizing hormone-releasing hormone neurons: estrogenic control of galanin gene expression. Endocrinology 98 ADa Mar; 139:939-948. [PubMed: 9492023]1998

Shen ES, Meade EH, Perez MC, Deecher DC, Negro-Vilar A, Lopez FJ. Expression of functional estrogen receptors and galanin messenger ribonucleic acid in immortalized luteinizing hormone-releasing hormone neurons: estrogenic control of galanin gene expression. Endocrinology 1998 Mar;139:939_ 948. [PubMed: 9492023]

Shivers BD, Harlan RE, Morrell JI, Pfaff DW. Absence of Oestradiol Concentration in Cell Nuclei of LHRH- Immunoreactive Neurones. Nature 1983;304:345-347. [PubMed: 6348552]

Skinner DC, Evans NP, Delaleu B, Goodman RL, Bouchard P, Caraty A. The negative feedback actions of progesterone on gonadotropin-releasing hormone secretion are transduced by the classical progesterone receptor. Proc Natl Acad Sci U S A 1998;95:10978-10983. [PubMed: 9724815]

Skynner MJ, Sim JA, Herbison AE. Detection of estrogen receptor alpha and beta messenger ribonucleic acids in adult gonadotropin-releasing hormone neurons. Endocrinology 1999;140:5195-5201. [PubMed: 10537149]

Smith JT, Clifton DK, Steiner RA. Regulation of the neuroendocrine reproductive axis by kisspeptinGPR54 signaling. Reproduction 2006;131:623-630. [PubMed: 16595713]

Spratt DP, Herbison AE. Regulation of preoptic area gonadotrophin-releasing hormone (GnRH) mRNA expression by gonadal steroids in the long-term gonadectomized male rat. Brain Res Mol Brain Res 1997;47:125-133. [PubMed: 9221909]

Stein B, Yang MX. Repression of the interleukin-6 promoter by estrogen receptor is mediated by NFkappa B and C/EBP beta. Mol Cell Biol 1995;15:4971-4979. [PubMed: 7651415]

Temple JL, Laing E, Sunder A, Wray S. Direct action of estradiol on gonadotropin-releasing hormone-1 neuronal activity via a transcription-dependent mechanism. J Neurosci 2004;24:6326-6333. [PubMed: 15254088]

Tena-Sempere M. GPR54 and kisspeptin in reproduction. Hum Reprod Update 2006;12:631-639. [PubMed: 16731583]

Titolo D, Cai F, Belsham DD. Coordinate regulation of neuropeptide Y and agouti-related peptide gene expression by estrogen depends on the ratio of estrogen receptor (ER) alpha to ERbeta in clonal hypothalamic neurons. Mol Endocrinol 2006;20:2080-2092. [PubMed: 16675543]

Titolo D, Mayer CM, Dhillon SS, Cai F, Belsham DD. Estrogen facilitates both phosphatidylinositol 3kinase/Akt and ERK1/2 mitogen-activated protein kinase membrane signaling required for long-term neuropeptide Y transcriptional regulation in clonal, immortalized neurons. J Neurosci 2008;28:64736482. [PubMed: 18562618]

von Lindern M, Boer L, Wessely O, Parker M, Beug H. The transactivation domain AF-2 but not the DNA-binding domain of the estrogen receptor is required to inhibit differentiation of avian erythroid progenitors. Mol Endocrinol 1998;12:263-277. [PubMed: 9482667]

Weiner RI, Martinez dIE. Pulsatile release of gonadotrophin releasing hormone $(\mathrm{GnRH})$ is an intrinsic property of GT1 GnRH neuronal cell lines. Hum Reprod 1993;8:13-7. 13-17. [PubMed: 7506268]

White MM, Sheffer I, Teeter J, Apostolakis EM. Hypothalamic progesterone receptor-A mediates gonadotropin surges, self priming and receptivity in estrogen-primed female mice. J Mol Endocrinol 2007;38:35-50. [PubMed: 17242168]

Wierman ME, Kepa JK, Sun W, Gordon DF, Wood WM. Estrogen negatively regulates rat gonadotropin releasing hormone (rGnRH) promoter activity in transfected placental cells. Mol Cell Endo 1992;86:1-10.

Wintermantel TM, Campbell RE, Porteous R, Bock D, Grone HJ, Todman MG, Korach KS, Greiner E, Perez CA, Schutz G, Herbison AE. Definition of estrogen receptor pathway critical for estrogen positive feedback to gonadotropin-releasing hormone neurons and fertility. Neuron 2006;52:271280. [PubMed: 17046690] 
Wolfe AM, Wray S, Westphal H, Radovick S. Cell-specific expression of the human gonadotropinreleasing hormone gene in transgenic animals. J Biol Chem 1995;271:20018-20023. [PubMed: 8702719]

Wray S, Zoeller RT, Gainer H. Differential Effects of Estrogen on Luteinizing Hormone-Releasing Hormone Gene Expression in Slice Explant Cultures Prepared From Specific Rat Forebrain Regions. Mol Endo 1989;3:1197-1206.

Yang-Yen HF, Chambard JC, Sun YL, Smeal T, Schmidt TJ, Drouin J, Karin M. Transcriptional interference between c-Jun and the glucocorticoid receptor: mutual inhibition of DNA binding due to direct protein-protein interaction. Cell 1990;62:1205-1215. [PubMed: 2169352]

Zhen S, Dunn IC, Wray S, Liu Y, Chappell PE, Levine JE, Radovick S. An alternative gonadotropinreleasing hormone $(\mathrm{GnRH}) \mathrm{RNA}$ splicing product found in cultured GnRH neurons and mouse hypothalamus. J Biol Chem 1997;272:12620-12625. [PubMed: 9139717]

Zoeller RT, Young WS. Changes in cellular levels of messenger ribonucleic acid encoding gonadotropinreleasing hormone in the anterior hypothalamus of female rats during the estrous cycle. Endocrinology 1988;123:1688-1689. [PubMed: 3042374] 
1)

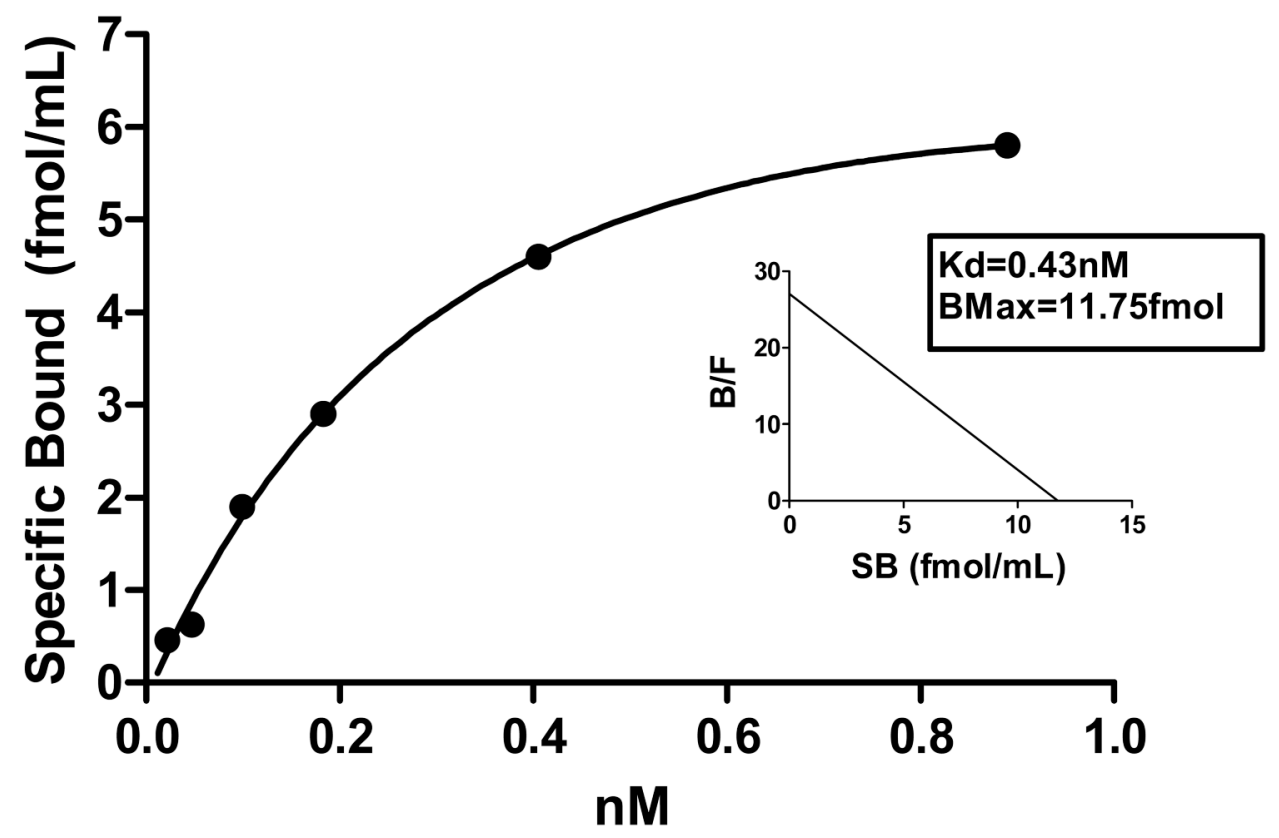

Figure 1. Saturation Binding Assay

GN11 cells were incubated with increasing amounts of $\left[{ }^{125} \mathrm{I}\right] \mathrm{E} 2$. Cells were co-incubated with or without cold E2 to calculate specific binding. Specific binding was plotted against radioligand concentration and non-linear regression analysis was used to analyze binding kinetics. A Kd of $0.43 \mathrm{nM}$ was calculated with a Bmax of $701.5 \mathrm{cpm}$. A Scatchard plot is shown as an inset plotting $\mathrm{B} / \mathrm{F}$ versus specific bound (SB). 
2A)
GN11 Cells

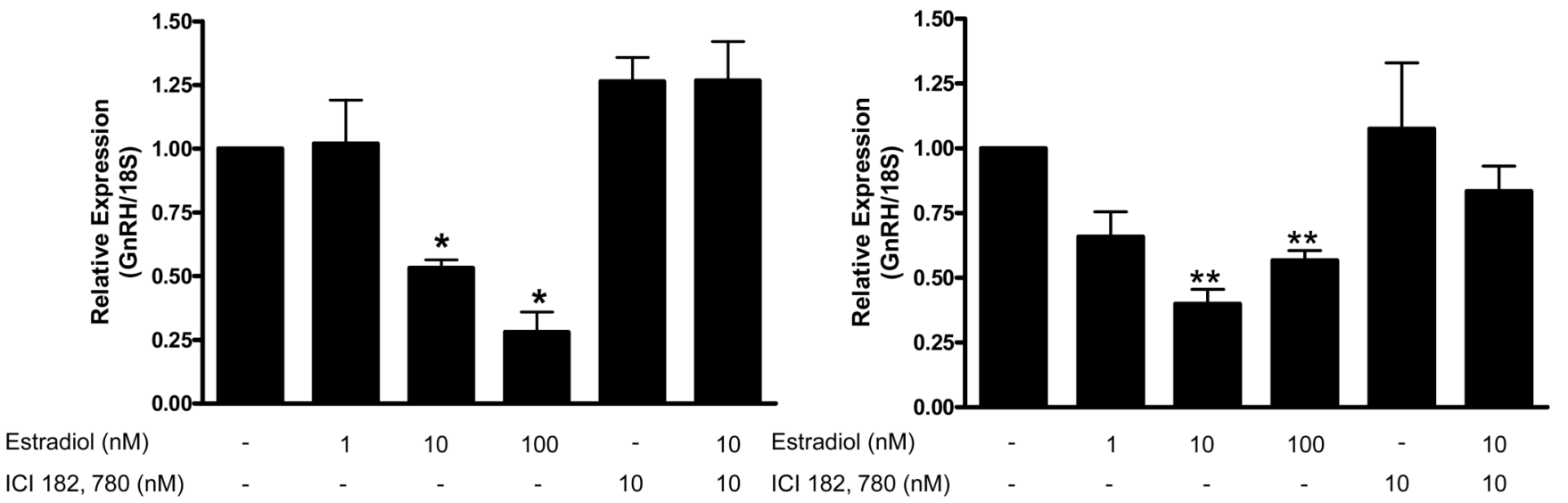

Figure 2. GnRH Gene Expression in GN11 and GT1-7 Cells Treated With 17ß-Estradiol

A) GN11 and B) GT1-7 neuronal cells were treated with either 1nM, 10nM, or 100nM of E2 for 16 hours. An estrogen receptor antagonist (ICI 182,780) was also used. Total RNA was extracted and quantitative real-time PCR was performed with primers specifically designed to amplify mGnRH. Data are expressed as the mean \pm SEM $(n=5) . *, p<0.001$ vs. control. **, $\mathrm{p}<0.05$ vs. control. 
3A)

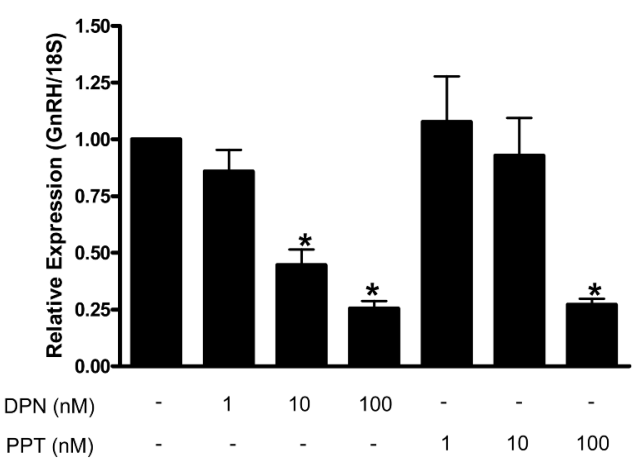

3B)

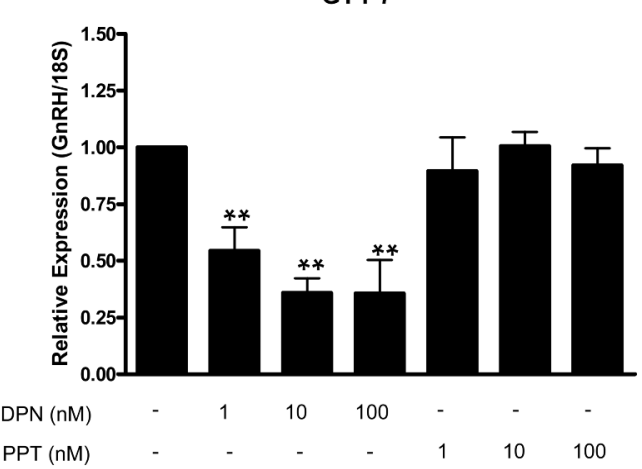

Figure 3. GnRH Gene Expression in GN11 and GT1-7 Cells Treated With Estrogen Receptor Agonists

A) GN11 and B) GT1-7 neuronal cells were treated with 1nM, 10nM, or 100nM of an ER $\beta$ agonist (DPN) or ER- $\alpha$ agonist (PPT) for 16 hours. Total RNA was extracted and quantitative real-time PCR was performed with primers specifically designed to amplify mGnRH. GN11 data is expressed as the mean \pm SEM $(n=6)$. GT1-7 data are expressed as the mean \pm SEM $(\mathrm{n}=5) . *, \mathrm{p}<0.001 v s$. control. **, $\mathrm{p}<0.05 v s$. control. 
4A)

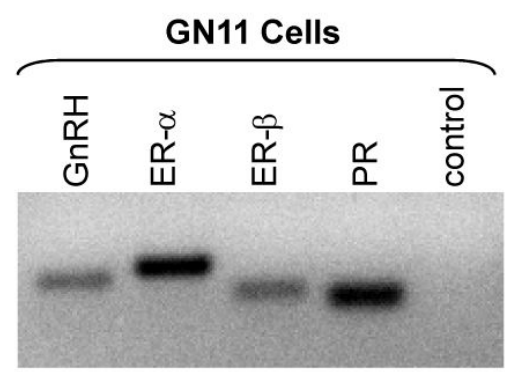

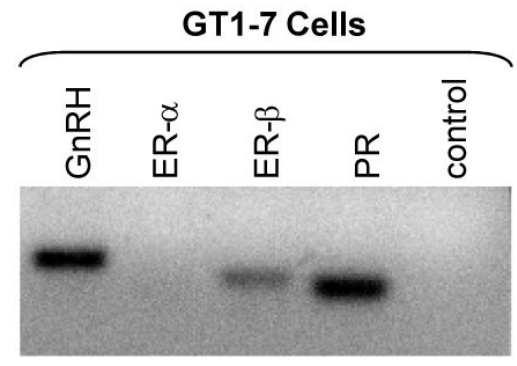

4B)

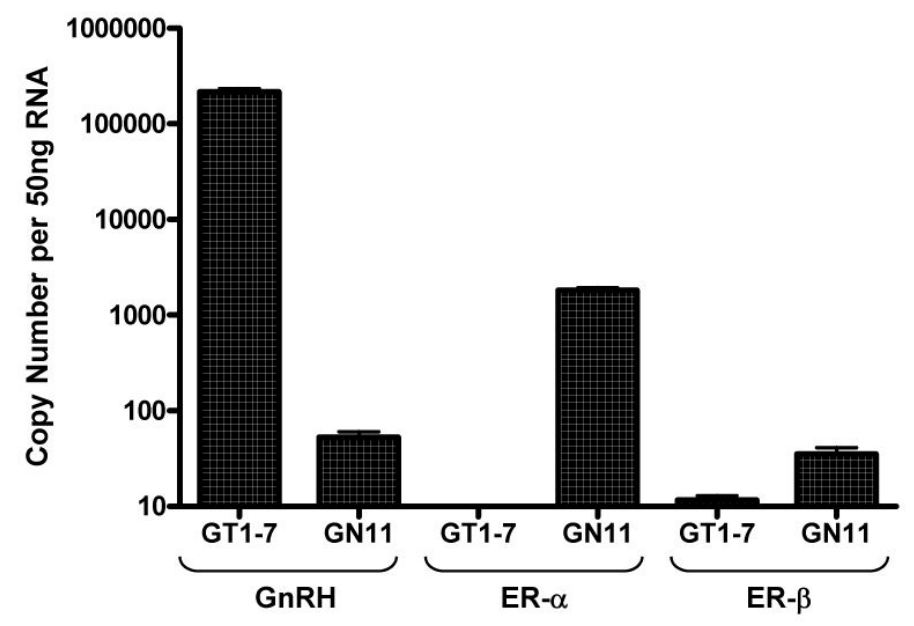

Figure 4. GnRH, ER $\alpha$ and ERß Gene Expression in GN11 and GT1-7 Neuronal Cell Lines Agarose gel of PCR products of RT PCR reaction using primers for the GnRH, ER $\alpha, E R \beta$, and PR gene in the respective cell lines. A 193 bp band is shown for mGnRH, a 234 bp band for $\mathrm{mER} \alpha$, a $146 \mathrm{bp}$ band for $\mathrm{mER} \beta$, and a $121 \mathrm{bp}$ band for mPR. RNA that was not reverse transcribed was used as a negative control. B) Graph charting quantities of GnRH, ER $\alpha$ and ER $\beta$ mRNA expression in GN11 and GT1-7 cells. A standard curve was produced using known quantities of GnRH, ER $\alpha$, or ER $\beta$ cDNA contained in a pGEMTeasy plasmid. Copy number of each gene in GN11 and GT1-7 cells were derived by calculating molar quantities of mRNA levels of each cell type. RNA that was not reverse transcribed was used as a negative control. 
5A)

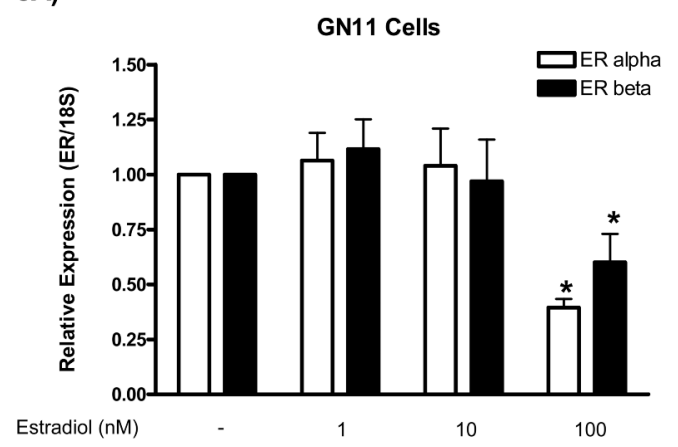

5B)

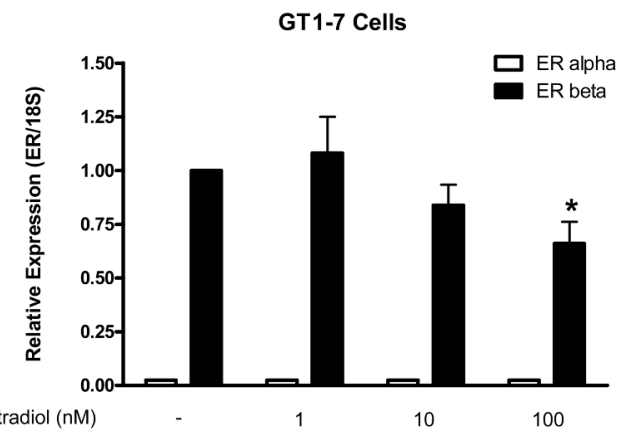

Figure 5. ER $\alpha$ and ERß Gene Expression in GN11 and GT1-7 Cells Treated With 17ß-Estradiol A) GN11 and B) GT1-7 neuronal cells were treated with 1nM, 10nM or 100nM of E2 for 16 hours. Total RNA was extracted and quantitative real-time PCR was performed with primers specifically designed to amplify $\operatorname{mER} \alpha$ and $\operatorname{mER} \beta$. GN11 data are expressed as the mean \pm SEM $(n=6)$. GT1-7 data are expressed as the mean \pm SEM $(n=4)$. *, p $<0.01$ vs. control. ** denotes values below detection limit of the assay. 
6A)

\section{GN11 Cells}

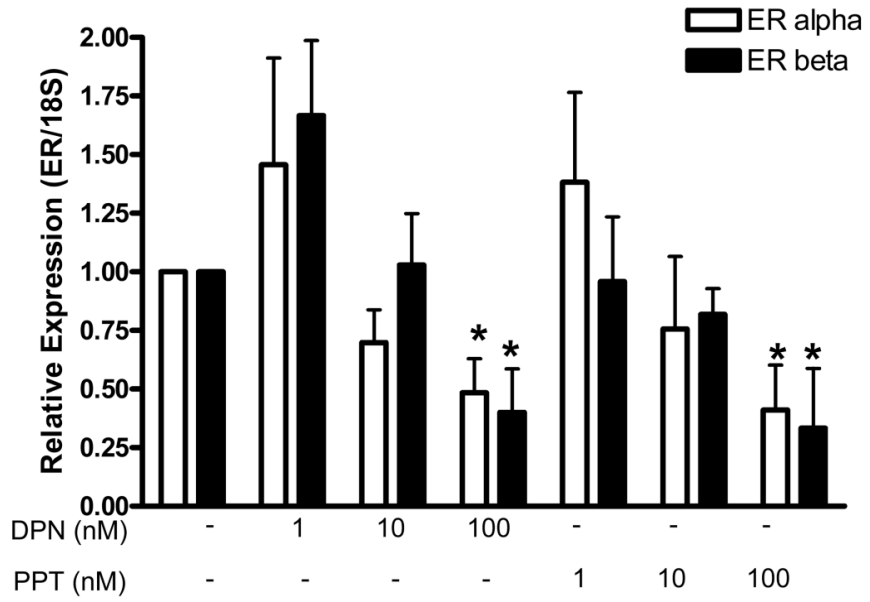

6B)

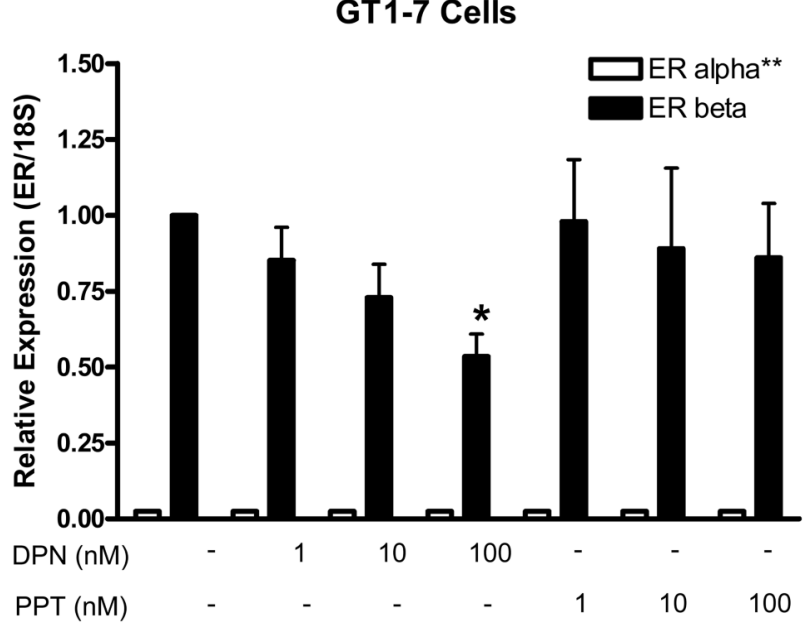

Figure 6. ER $\alpha$ and ERß Gene Expression in GN11 and GT1-7 Cells Treated With Estrogen Receptor Agonists

A) GN11 and B) GT1-7 neuronal cells were treated with 1nM, 10nM, or 100nM of an ER $\beta$ agonist (DPN) or ER $\alpha$ agonist (PPT) for 16 hours. Total RNA was extracted and quantitative real-time PCR was performed with primers specifically designed to amplify $\mathrm{mER} \alpha$ and mER $\beta$. GN11 data are expressed as the mean \pm SEM $(n=6)$. GT1-7 data are expressed as the mean $\pm \operatorname{SEM}(\mathrm{n}=4) . *, \mathrm{p}<0.01 v s$. control. **denotes values below detection limit of the assay. 
7A)

GN11 Cells

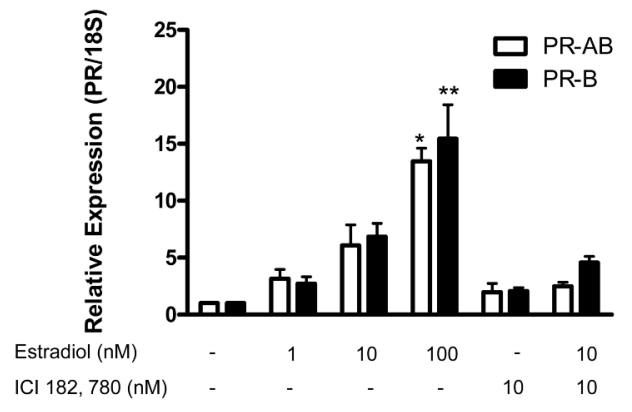

7C)

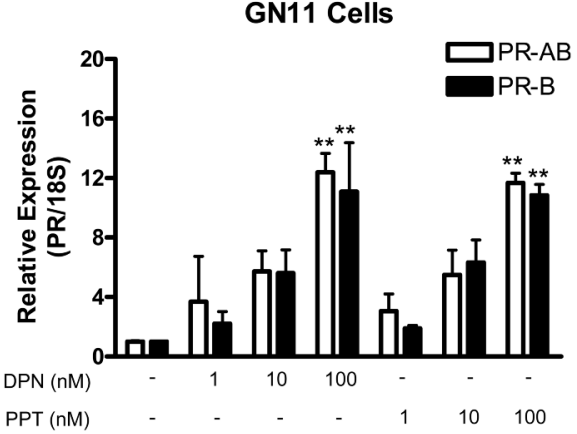

7B)
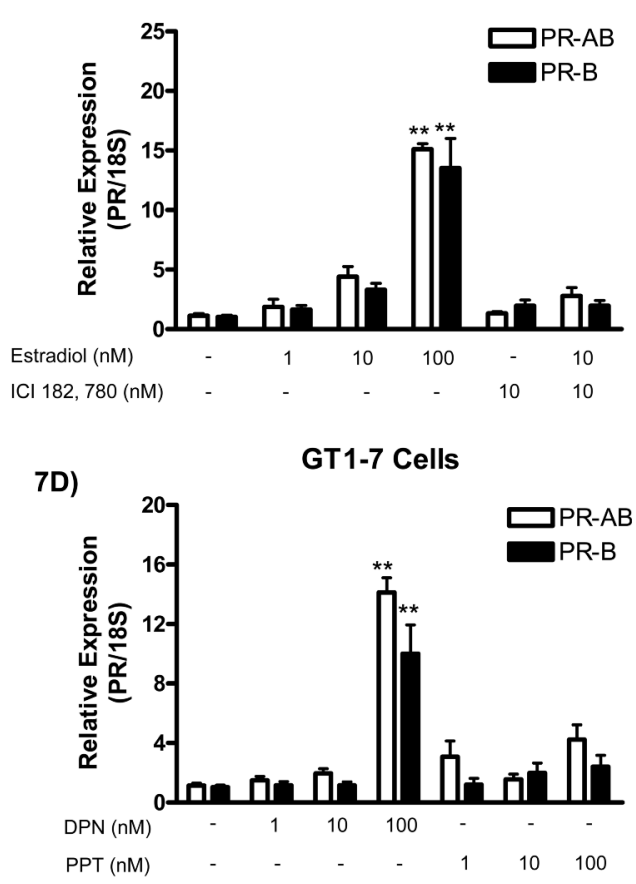

Figure 7. mPR Gene Expression in GN11 and GT1-7 Cells Treated With 17ß-Estradiol GN11 A) and GT1-7 B) neuronal cells were treated with 1nM, 10nM, or 100nM of E2 for 16 hours. An estrogen receptor antagonist (ICI 182,780) was also used. GN11 C) and GT1-7 D) neuronal cells were also treated with $1 \mathrm{nM}, 10 \mathrm{nM}$, or $100 \mathrm{nM}$ of DPN or PPT. Total RNA was extracted and quantitative real-time PCR was performed with primers specifically designed to amplify either both isoforms of the PR (PR-AB; PR-A and PR-B) or only the long form (PRB) Data is expressed as the mean $\pm \operatorname{SEM}(n=3)$. ${ }^{*}, p<0.01 v s$. control. **, $p<0.001$ vs. control. 